\title{
Incidence and Distribution of Rice Insect Pests and Their Natural Enemies in Rice Growing Area of South Gondar, Ethiopia
}

\author{
Geteneh Mitku* Muluadam Birhan Desalegn Yalew \\ Ethiopian Institute of Agricultural Research Institute, Fogera national rice research and training center; \\ P.O.BOX 1937, Bihar Dar
}

\begin{abstract}
Since rice crop production relatively is recent activities in Ethiopia, the incidence and distribution of insect pests and their natural enemy in the study area has not been recognized. Field surveys were conducted in 2018 and 2019 rainy season to generate baseline information on the type of pests prevailing in rice crop. The survey was conducted in South Gondar, three districts. Insect pests were determined by visual search for damages done by insects throughout the field. The current survey found that more than 13 insect pest of namely, stalk eyed fly, stem borer, leaf hopper as leaf/stem feeding and rice bug and sting bugs are among grain sucking insect pest, and whorl maggot, cricket, grass hopper and termite also found in the study area. Furthermore, our study found that a new insect in the study area named as creatonatus sp. which feed on rice leaf. Additionally, the study found that more than 6 natural enemies of rice insect pests. Some of the natural enemies are damselfly, dragonfly and spider, beetle, lacewing and wasps found dominantly in the study area. This study is the first report to explore the presence of these above maintained insect pest and natural enemy in the rice growing area of south Gondar. It then requires adequate knowledge about all mentioned insects yield loss on rice production. The infestation level of natural enemy on rice insect should be checked and farmers should be awared regarding to importance of these natural enemy for rice insect pest control.
\end{abstract}

Keywords : rice insects, natural enemy, incidence, south Gondar

DOI: $10.7176 / \mathrm{PPAR} / 11-9-03$

Publication date:May $31^{\text {st }} 2021$

\section{Introduction}

Rice (Oryza sativa L.; Poaceae) is one of the most widely cultivated cereals and globally important food crops (Nascimento et al. 2015). Besides, it provides more calories per hectare than any other cereals food grain. Although rice cultivation and utilization as a food crop in Ethiopia is recent phenomenon (Abdu et al., 2013), it is an important staple food crop grown in wetland, where other crops do not grow, due to water loge effect. According to Gebey et al., 2012, report rice introduced in Ethiopia after the wild rice (O. longistaminata) was observed in the swampy and waterlogged areas of Fogera and Gambella plains even though it is recently introduced, the government of Ethiopia has given due emphasis as a millennium crop for assuring food security and as an income source (Astewl, 2010).

Wetland agriculture, which comprises crop cultivation, livestock, pisciculture, and fishing, has made a significant contribution to the well-being of humanity over the centuries (Bayliss-Smith and Golson 1992). Currently wetlands area in Fogera, Dera and LiboKemkem plain is the main rice production because of their high water availability and enough soil fertility.

The importance and production of rice in Ethiopia is highlighted in the rice crop production package Ethiopia, which exemplify that growing area increased from 10 thousand hectares to 63 thousand hectares, while production increased from 7.1 thousand tones to 171 thousand tons between 2006 and 2011. According to MoARD, 2010, report Amhara, Southern Nations, Nationalities and Peoples Region (SNNPR), Oromiya, Somali, Gambella, BeniShangul Gumuz, and Tigray regions are the significant producing areas in Ethiopia. Amhara region takes the major of production share which accounted for $44 \%$ of the area coverage and $40 \%$ of the production in the year 2009 , followed by the SNNPR which contributes $18.7 \%$ of the area coverage and $18.6 \%$ of the production in the same year.

Currently rice production in South Gondar, for instance Fogera District is dominant and major life changing crop for smallholder farmers than other crops. 
Figure 1 showed that the rice production trend in Ethiopia, the trend indicates high increasing rate especially since 2006.

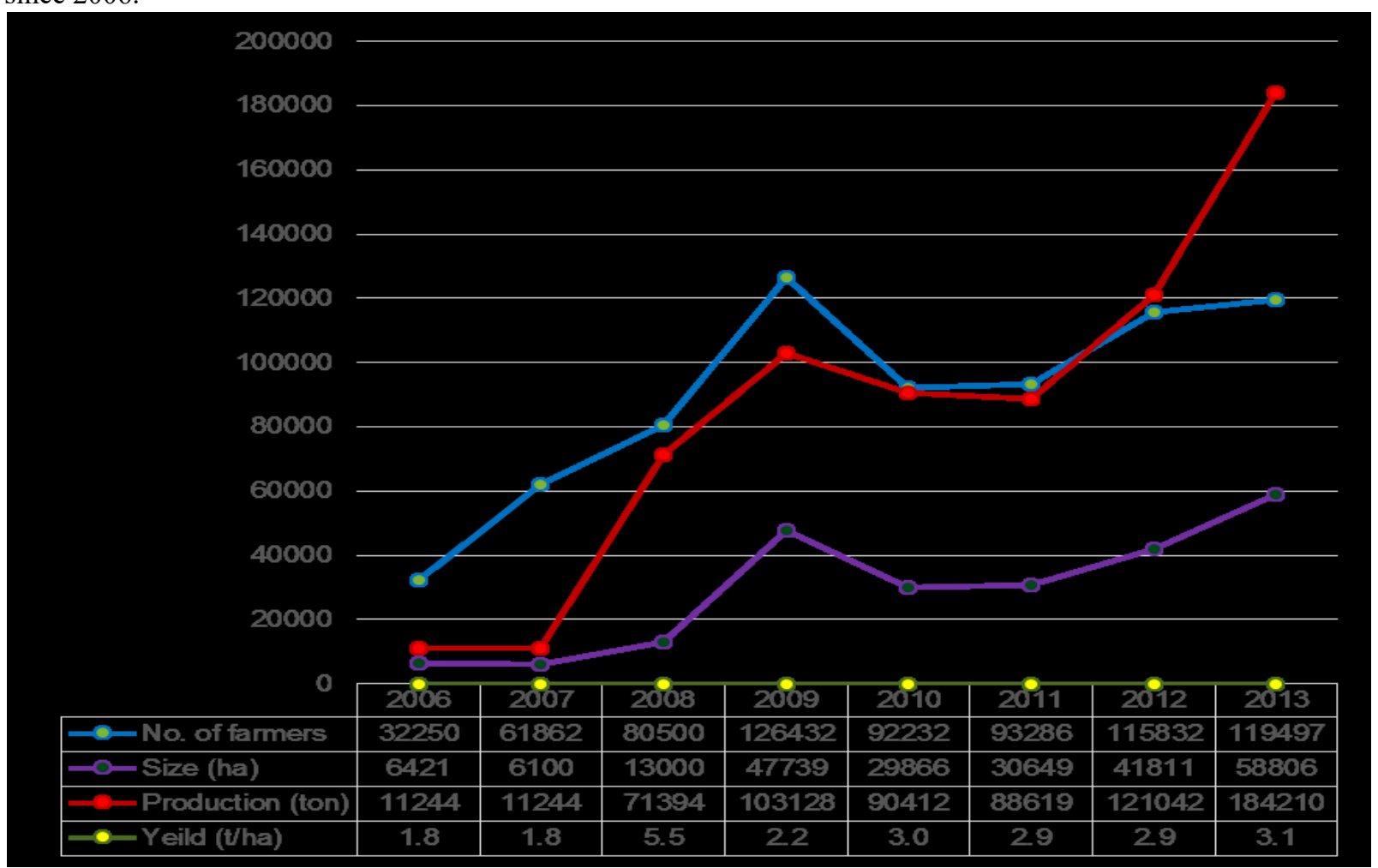

Source; $6^{\text {th }}$ CARD General Meeting 2015 (Dr. Dawit Alemu)

Although efforts have been made to increase the rice production and productivity through the improvement of the varieties and farming systems, the average yield is still below world rice productivity. Low yield attributed by different biotic and abiotic constraints. According to (Chen et al, 2011) study carried out in Nigeria, one major reason for the low yield is insect pests. Insect pests constitute one of the major yield reducing factors in (Pingali, and Gerpachio, 1997). Similar report Insect pest damage to rice crop were reported by CFC (2012) and Kadigi et al. (2008) who identified two kinds of constraints facing rice production in Tanzania, namely, biotic and abiotic. Losses due to insect pests in the developing countries of Africa have been estimated at about $20 \%$ (Diagne et al., 2013). The other study showed that grown in different agro-climatic conditions can be damaged by more than 100 species of insect pests, these insect pests' cause enormous grain yields losses, which may vary from $20-50 \%$ if not managed in time (KrishiK., 2005). Report by IRRI et al. (2010) shows an estimation of rice yield loss due to insects in Africa ranging between 10 and $15 \%$.

A wide range of organisms deliver ecological functions to provide biological control including insectivorous birds (García et al., 2018), ladybugs (Jacobsen et al., 2019), spiders (Happe et al., 2019), nematodes (Nermut et al., 2019), parasitoids (Hong-xing et al., 2017) and microorganisms (Van Lenteren et al., 2018). Increasing on-farm biodiversity of natural enemies is known to enhance biological control (Dainese et al., 2019). For example, a greater richness and abundance of natural enemies ensures more mechanisms by which different prey are consumed across environments and over time (Letourneau et al., 2009). However, the uneven effectiveness of natural enemies for pest suppression does need to be taken into account (Greenstone et al., 2010). Although there is considerable ecological research in the world on the organisms underpinning biological control (Chaplin-Kramer et al., 2011), no any research on rice insect of biological control and the organisms involved has been In Ethiopia.

Different research has been carried out to increase rice production and profitability in the Fogera, Dera and LiboKemkem wetlands. Some of those studies include integrated fertilizer management (Tilahun et al. 2013), value chains (Birhanu 2017), water availability and management as affected by livestock (Alemayehu 2013), climate change (Gashaw 2016), and nonpoint pollution in the Lake Tana basin (Moges et al. 2017). However, insect pests are important rice production constraint; there is limited research on the incidence and distribution of rice insects and their natural enemy. Identifying the insect pest found in rice growing area is very important because insects have different activities, and different ways to damage the crop (Mason and Mcdonough, 2012). The necessity of identification of the insects may lead to the controlling and management of the insect pests. This study is, therefore conducted to determine the diversity and distribution of the insect pests in rice growing area of South Gondar. 


\section{Material and Method}

A survey was conducted in fields of major rice growing areas of Ethiopia; in Fogera, Dera and LiboKemkem districts of South Gondar in 2017, 2018 and 2019 cropping seasons. The altitude of surveyed fields ranged from 1774 to 2415 m.a.s.l. Rice crop growth divided into three different stages, i.e. seedling (thereafter panicle initiation), flowering and ripping. The pests were collected on the three divided growth stage from each field. At every $5-10 \mathrm{Km}$ intervals along accessible roads, several plants in a cross diagonal line were examined for presence or absence of insect pests and associated natural enemies. The reason to do survey at three rice growth stage; different insects have different feeding habit and preference. Where insect infestation was encountered, the type of insect was identified and visual estimate of damage taken. In all areas covered by the survey, sampling of insects was extended to alternate host plants near the crop, in order to identify the host plants. The collected rice field insect pests were also identified from the literature collected from IRRI and Internet sources. The new insect found in the study area named as Creatonatus sp. was identified by Canada pest control organization.

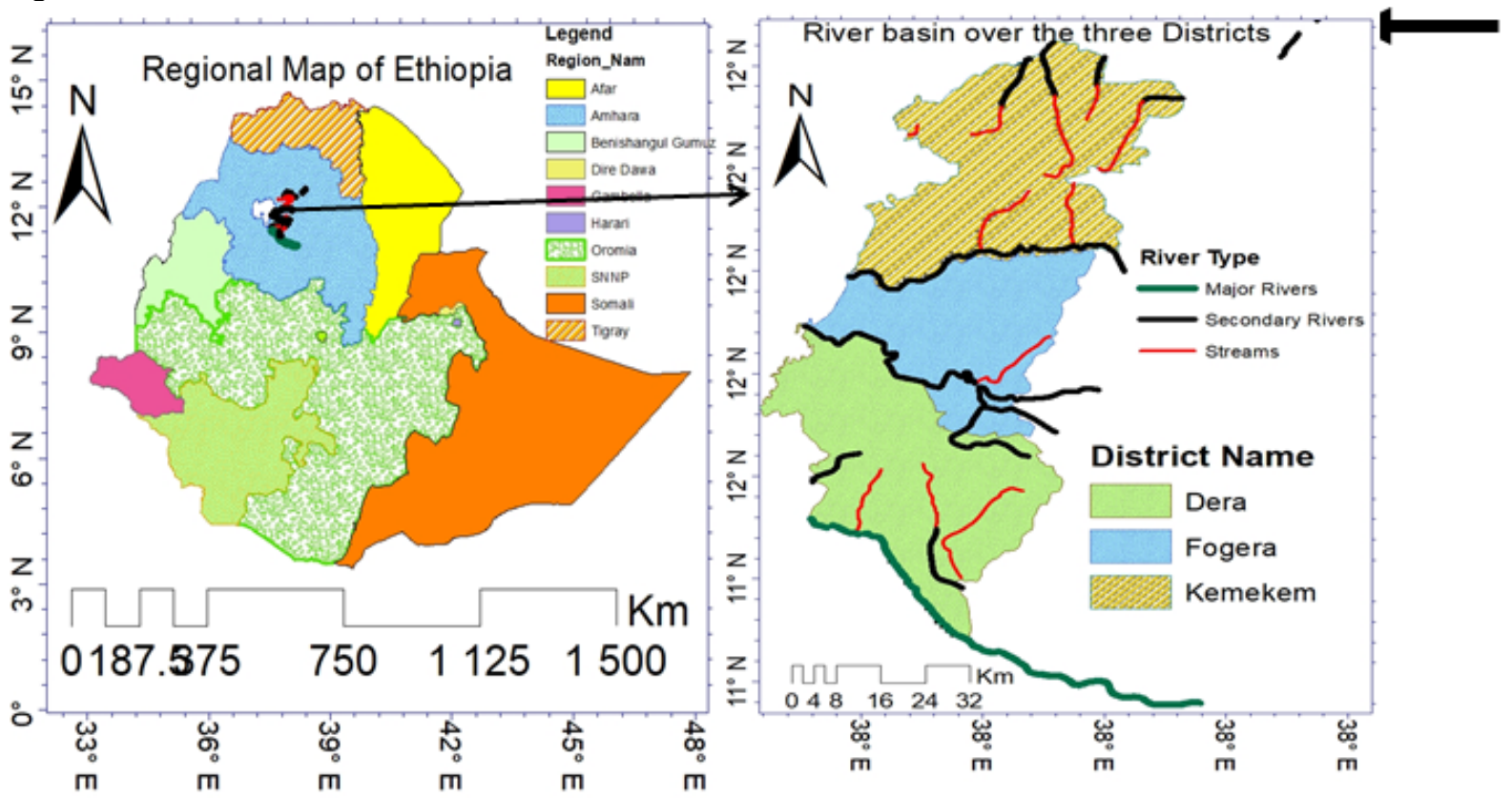

Figure 2 showing all surveyed districts in south Gondar, Amhara Region, Ethiopia.

\subsection{Data Collected and Analysis}

Insect infestation was encountered, the type of insect was identified and visual estimate of damage taken, number of insect pests and natural enemies per field found in the survey area were collected and analyzed using SPSS software.

\section{Result and Discussion}

\subsection{Rice agronomic practice and production system}

All crop production practices affect insect pest populations either positively or negatively. Hence during the current study, our survey assessed agronomic practices carried out by rice producer in the study area. Those agronomic practices were draining a rice field, transplanting, crop rotation, and fertilization. Even though direct seeding onto dry soil is not advantageous to aquatic pests such as the rice water weevil, almost all current surveyed area farmers practice direct seeding and broadcast planting method. Recently very few farmers used row planting methods. On the other aspect of agronomic practice all of the surveyed fields of rice production were by rain-fed system. In rainy season in all three study area, the rice production was dominant and it is in cluster base. Regarding to the crop rotation, in each year the rice crops grown in rainy season (June-November) and then followed by non-rice crop (mostly vegetable, and grass pea) by irrigation (from December -May) this practice perhaps removes the pests' food source and reduce their population buildup. Even though, continuous single cropping year to year allows exponential insect population growth and increase abundance of insect, some current fields in the study area used continuous rice cropping year to year. In the other aspect of agronomic practice, flooding the field after harvest mainly recommended for controlling stem borers, though this practice is not totally known in the study area. Mostly used fertilizers in the study area were nitrogen and phosphorous. 


\subsection{Incidence of insect pests in rice growing area of South Gondar zone, Ethiopia.}

More than 13 rice main insect pests were found in the study area which belonging to different taxonomic order. Insect pests found in the current study area categorized in to three major categories namely, leaf/stem feeding, grain sucking insect, and root feeding insect pests. Regarding to leaf/stem feeding insects, the current study found that, four major leaf/stem feeding insects; stalk eyed fly, leaf hopper, plant hoper and stem borer (Table 1). These above mentioned insects mostly feed the rice between tillering and heading stage. In the other view, two grain sucking insect namely sting and rice bug, found throughout the study area (Table1). Additionally, our study found, that case worm, termite, whorl maggot and armyworm in the study area.

Although the rice crop was infested by the aforementioned insect pests, the maximum severity was $15.55 \%$ and $15.73 \%$ by leaf borer and stalk eyed fly respectively (Table 1). Whorl maggot infested $12.64 \%$ of the rice fields (Table 1). The remaining insect pests' infestation was below $10 \%$, which suggests that the insect incidence is widespread but the infestation is low in the study area. Which means that the, Creatonatus sp., leaf folder, whorl maggot, and armyworms with low visible infestation damage symptoms; however, the damage is rarely enough to reduce yield because the crop can compensate for early damage over the rest of the growing season. Creatonatus sp. which is a new insect pest, mostly occur at reproductive stage.

The low insect infestation may be due to the presence of natural enemy of the insect pest which suppresses the insect from damage. Additionally low incidence and infestation perhaps due to rice variety has resistance ability to aforementioned rice insect pests. The other possibility of low incidence and severity may due to different cultural practice used in the study area. This study suggests and gives some indication about the incidence of rice insect pests in different areas of the study area.

Table 1 showed that insect pest found in rice production area of south Gondar

\begin{tabular}{lcccc}
\hline \multicolumn{2}{c}{ Insect Pests } & upland & lowland & Infestation (\%) \\
\hline Common name & S. name & & & \\
Stalk eyed fly & Diopsis longicornis & + & ++ & \\
G leaf hopper & Nephotettix nigropictus & ++ & ++ & 15.73 \\
B leaf hopper & & + & + & 9.91 \\
Stem borer & Maliarpha separatell & ++ & ++ & 15.55 \\
Gall midge & Orseolia oryzivora Harris & + & + & 2.91 \\
Sting bug & Aspavia armigera F & + & + & 0.0 \\
Rice bug & Leptocorisa oratorius & + & + & 0.8 \\
Grasshopper & Caelifera spp. & + & + & 2.00 \\
Termite & Macrotermes spp. & + & -- & 1.27 \\
Whorl maggots & Hydrellia spp. & + & + & 0.00 \\
Creatonatus spp. & Creatonatus spp. & ++ & ++ & 12.64 \\
Leaf worm & Nymphula depunctalis & + & -- & 8.45 \\
Rice leaf folder & Marasmia trapezalis & + & + & 5.36 \\
Army worm & Spodoptera frugiperda & - & + & 0.0 \\
\hline
\end{tabular}

+++: Widely abundant, ++: Abundant, +: Present, -: Not recorded

\subsection{Incidence of insect pest in the study area}

The current survey carried out in three districts with total of 40 fields at three rice growth stage which found that the stalk eyed fly, leaf hopper and stem borer with the average number of 16.37, 10.50 and 4.93 insects per field respectively (Table 2). Additionally, our study reveled that rice bug and sting bugs are among grain sucking insect pest found with the average number of 4.13 and 2.58 in the study area. Whorl maggot found in all surveyed area with average number of 13.1, 11.2, and 9.7 insects per field in Fogera, Dera and Libokemkem districts respectively. Leaf hoppers found in all surveyed area with average number of 12.2, 11.1, and 8.2 insects per field in Fogera, Dera and Libokemkem districts respectively. Both Green and brown leaf hopper insects found in the study area which cause damage of rice crops by sucking the sap and by plugging xylem and phloem with their feeding sheaths and pieces of tissue pushed into these vessels during exploratory feeding. The survey also showed that the average number of caseworm was 11.2, 9.3, and 7.6 in Fogera, Dera and Libo Kemkem lowland fields. Caseworm is semi aquatic in nature, hence the larvae occurs only in lowland swamp, where they are most abundant.

Overall, the current study found that, stalk eyed fly, Creatonatuse sp., whorl maggot and leaf hopper and were the most dominant insect pest in the lowland while termite, army worm, sting bug, and rice bug hade low incidence in the study area (Table 2). In respect to insect distribution difference, all surveyed districts had nearly similar distribution of insect pest. Termites found only in the upland, however, the population intensities of termites were much less than the population intensity of other pests (Table 2). 
Table 2 showed that the number of insects/ field

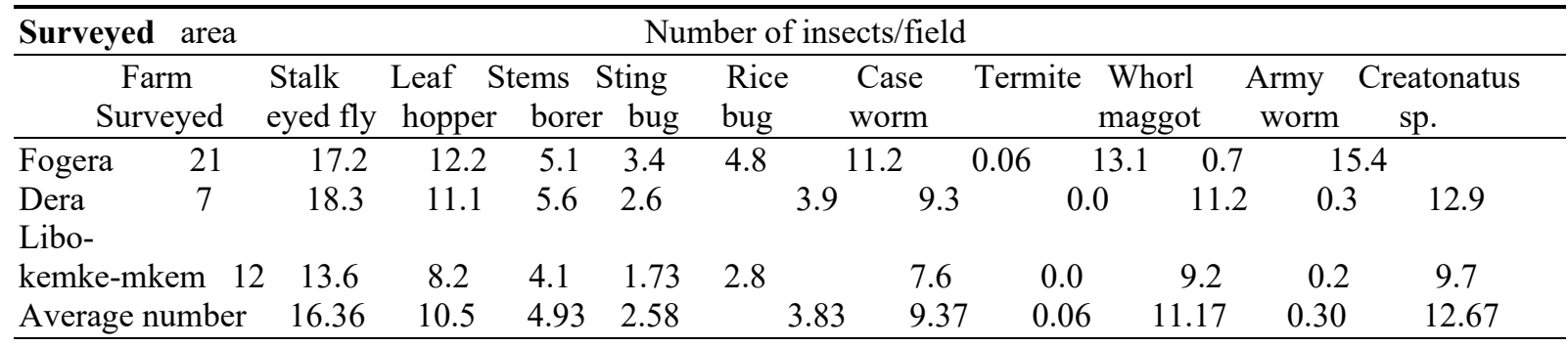

\subsection{Natural enemy of rice insect pest found in the rice production area of south Gondar}

Both predators and parasitoids which attacked most of the rice insect pest in found in the study area (Table 3). In the current surveyed area more than 6 types of natural enemy were found (Table 3). Damselfly, dragonfly and spider found dominantly in all study area; especially in the wetland area; they noted when they pray on moving adults and nymphs stem borer and leaf hoper. Spiders found in all assessed districts which attack adult moths, and also caught by webs while flying. Other natural enemy such as the crickets, found in all study area with low density, they noted when they feed on eggs of moth. Furthermore the other predatory found in the study area was coccinellid which seen when pray on stem borer; those found with low density in the study area. In addition to predatory, parasitoid (wasps) also found with low density; which parasitized eggs of leaf hopper.

In general, low density of rice insect pest in the study area, perhaps due to the presence and effect of those above mentioned natural enemy. Hence, the conservation of this valuable natural enemy is the key to development of stable and successful integrated pest management (IPM) systems. In the current study area, natural enemy of rice insect pest reported during the survey period; which means that this is the first report in regard to announce the presence of rice insect pest natural enemy.

Table 3 Showed that some of natural enemy found and attack insects in the study area

\begin{tabular}{lllc}
\hline \multicolumn{1}{c}{ Order } & Common name & Scientific name & $\begin{array}{c}\text { Natural enemy } \\
\text { type }\end{array}$ \\
\hline Odonata & Damselfly & Chrysoperla carnea (Stephens) & Predator \\
Odonata & Dragonfly & Diplacodes sp & Predator \\
Arachnoidea & Spiders & Spiders & Predator \\
Coleoptera & Coccinellid & Chilocorus stigma (Say) & Predator \\
Hymenoptera & Wasp & Cheilomenes spp.) & Predator \\
Neuroptera & Lacewings & Meteorus autographae $M$. & Parasitoid \\
\hline
\end{tabular}

\section{Conclusion and Recommendation}

More than 13 different rice insect pests found in the rice growing areas of South Gondar. The Stalk eyed fly, Creatonatus sp. (new insect found in the study area), case worm, whorl maggot, leaf hopper, sting bug, stem borer and rice bug are the common pest of lowland in Fogera, Dera and Libokemkem District, South Gondar. Sting bug and rice bug are commonly feed on the reproductive stage; which mostly observed at maturity stage. Stalk eyed fly, leaf hopper,, and stem borer infestation observed at the early rice growth stage. These most of aforementioned insect pest infestation were below $10 \%$ which means that the economic losses due to the insects may be low this perhaps the presence of effective natural enemy of the insect pests. According to Geteneh et al (2020 unpublished data), report even though there are different insect pests, almost all rice growers did not apply any insecticides for the control of rice insect pest. Hence the increased use of pesticides which apart from increasing crop production, have long term negative effects on Fauna and flora, which will then change soil characteristics and hence reduced production (Edmeades, 2003). In general the low insect infestation may perhaps due to the presence of effective natural enemies, or other cultural practice used by the farmers.

Different natural enemies of rice pests have been recorded in the three rice growing area of south Gondar, Ethiopia. More than 6 natural enemies is list out in the study area; but the level of infestation for each specific natural enemy on different insect should be evaluated for their levels of control against all insect pests including Creatonatus sp. under laboratory condition.

Sustainable and efficient rice pest management practices for the current study area require scientific research on the effect of individual rice insect and their natural enemies.

In general from the above result it is recommended that the effects of natural enemies on growth and reproduction of herbivores and yield loss of rice due to insect pests should be studied, similarly ability of currently used rice variety for insect resistant and effect of different cultural practice should be evaluated for upcoming rice pest management strategy establishment. 


\section{Acknowledgment}

The author thanks Endalew Assefa for his help for study area map preparation. The Funding was provided by EIAR.

\section{Reference}

[1] Abdu S, Nonglak P, Prapa Sripichitt and Sreewongchai T. Identification of blast resistant varieties from landrace, improved and wild species of . Thailand. Kasetsart J. Nat. Sci. (2013) 47: 1-7.

[2] Alemayehu M (2013) Livestock-water interactions: the case of Gumara Watershed in the Upper Blue Nile Basin, Ethiopia. PhD thesis. Humboldt University of Berlin, Berlin.

[3] Astewl, T. (2010). Analysis of rice profitability and marketing chain: The case of Fogera woreda, South Gondar Zone, Amhara National Regional State, Ethiopia [MSc Thesis]. Department of Agricultural Economics, Haramaya University.

[4] Bayliss-Smith T, Golson J (1992) Wetland agriculture in New Guinea Highlands prehistory. In: Coles B (ed) The wetland revolution in prehistory: 15-27. Exeter: The Prehistoric Society and Wetland Archaeological Research Project.

[5] Birhanu T (2017) Water-induced shift of farming systems and value addition in Lake Tana sub-basin: the case of rice production and marketing in Fogera District, northwestern Ethiopia. In: Stave K, Goshu G, Aynalem S (eds) Social and ecological system dynamics. AESS Interdisciplinary Environmental Studies and Sciences Series. Springer, Cham.

[6] CFC (Common Fund for Commodities). (2012). Rice Sector Development in East Africa: A desk study prepared for the Common Fund for Commodities. European Cooperative for Rural Dev. P 73.

[7] Chen, M., A. Shelton and G.Y. Ye, 2011. Insect-resistant genetically modified rice in China: From research to commercialization. Annu. Rev. Entomol., 56: 81-101.

[8] Chaplin-Kramer, R., O’Rourke, M.E., Blitzer, E.J., Kremen, C., 2011. A meta-analysis of crop pest and natural enemy response to landscape complexity. Ecol. Lett. 14, 922-932.

[9] Dainese, M., Martin, E.A., Aizen, M.A., Albrecht, M., Bartomeus, I., Bommarco, R., Carvalheiro, L.G., et al., 2019. A global synthesis reveals biodiversity-mediated benefits for crop production. Science Advances 5 (10).

[10] Diagne, A.; Alia, D.Y.; Amovin-Assagba, E.; Wopereis, M.C.S.; Saito, K.; Nakelse, T. Farmer perceptions of the biophysical constraints to production in sub-Saharan Africa, and potential impact of research. In Realizing Africa's Promise; Wopereis, M.C.S., Johnson, D.E., Ahmadi, N., Tollens, E., Jalloh, A., Eds.; CABI: Accra, Ghana, 2013; pp. 46-68.

[11] Elazegui, P.A., Soriano, J., Bandong, J., Estorninos, L., Jonson, I., Teng, P.S., Shcpard, B.M., Litsinger, J.A., Moody, K. Sc Hihino, H., 1990. Methodology used in the 1KK1 Integrated l'est Survey. In: Crop loss assessnient in . IRRI, Los Baños. pp. 33-27 I. ; Forrester, J.W., IY61. Industrial dynamics. MIT-Press, Cambridge, Massachusetts. 164 p. Greenacre, M.J.,1984. 'I'heory and applications of correspondence analysis. Academic Press, London. 364 p.

[12] Happe, A.-K., Alins, G., Blüthgen, N., Boreux, V., Bosch, J., García, D., Hamback, P.A., Klein, A.-M., Martínez-Sastre, R., Mi narro, M., Müller, A.K., Porcel, M., Rodrigo, A., Roquer-Beni, L., Samnegård, U., Tasin, M., Mody, K., 2019. Predatory arthropods in apple orchards across Europe: responses to agricultural management, adjacent habitat, landscape composition and country. Agric. Ecosyst. Environ. 273, 141-150.

[13] Improving Productivity and Market Success (IPMS) (2005) Fogera wereda pilot learning site diagnosis and program design. Kothari C. R. 2004.

[14] IRRI, Africa Rice, CIAT (2010). Global Rice Science Partnership (GRiSP). International Rice Research Institute, Los Baños, Philippines; Africa Rice Center, Cotonou, Benin; and International Center for Tropical Agriculture, Cali, Colombia

[15] Gashaw G (2016) Evaluating the effect of climate change and land use/cover change on catchment hydrology of Gumara watershed. Volume 3 Issue 1, 2015 Open Water Symposium, Addis Ababa, Ethiopia.

[16] Greenstone, M.H., Szendrei, Z., Payton, M.E., Rowley, D.L., Coudron, T.C., Weber, D.C., 2010. Choosing natural enemies for conservation biological control: use of the prey detectability half-life to rank key predators of Colorado potato beetle. Entomol. Exp. Appl. 136, 97-107.

[17] Gebey, T., Berhe, K., Hoekstra, D., \& Bogale, A. (2012). Rice value chain development in Fogera woreda based on the IPMS experience. ILRI.

[18] Kadigi RMJ, Kashaigili JJ, Mdoe NS (2004). The economics of irrigated paddy in Usangu Basin in Tanzania: Water utilization, productivity, income and livelihood implications. Physics and Chemistry of Earth 29:1091-1100.

[19] Kenniore, P.E., Heong, K.L. IC: Putter, C.A., 1985. Political, social. and perceptual aspects of integrated pest management programnir:s. In: Lee, B.S., Lok, W.H. \& Heong, K.L. (Eds), Proceedings of the Seminar on Integrated Pest Management in Malaysia. 16-17 January 1984. 
[20] Kuala Lumpur, Malaysia. Malaysian Plant Protection Society, Kuala Lumpur. pp.47-hY. Zadoks, J.C., 1985. On the conceptual hasis of crop loss assessnient: the threstiold theory. Annual Revue of Phytopathology 13: 4.55473

[21] Mason, Linda, J. \& McDonough, M. 2012. Biology, behavior, and ecology of stored grain and legume insects. Stored product protection. 7.

[22] MoARD (Ministry of Agriculture and Rural Development). 2010. National Research and Development Strategy of Ethiopia.The Federal Democratic Republic of Ethiopia, Ministry of Agriculture and Rural Development, Addis Ababa, Ethiopia. 48pp.

[23] Letourneau, D.K., Jedlicka, J.A., Bothwell, S.G., Moreno, C.R., 2009. Effects of natural enemy biodiversity on the suppression of arthropod herbivores in terrestrial ecosystems. Annu. Rev. Ecol. Evol. Syst. 40, 573592.

[24] Mesfin A, Mohammed A, Melanie DN (2016) Patterns, causes and consequences of land use/cover dynamics in the Gumara watershed of lake Tana basin, Northwestern Ethiopia. Environmental Systems Research 5:8

[25] Millennium Ecosystem Assessment (2005) Ecosystems and human well-being: synthesis. Island Press, Washington, DC, 102 pp. + app

[26] Nascimento JB, Barrigossi JAF, Borba TCO, Martin JFS, Fernandes PM, Mello RN. 2015. Evaluation genotypes for sugarcane borer resistance using phenotypic methods and molecular markers. Crop Protection 67: 43-51.

[27] Pingali, P.L.; Gerpachio, R.V. Living with reduced pesticide use in tropical in Asia. Food Policy 1997, 22, $107-118$.

[28] Nermut, J., Zemek, R., Mracek, Z., Palevsky, E., Půza, V., 2019. Entomopathogenic nematodes as natural enemies for control of Rhizoglyphus robini (Acari: Acaridae)? Biol. Contr. 128, 102-110.

[29] Van Lenteren, J.C., Bolckmans, K., K€ohl, J., Ravensberg, W.J., Urbaneja, A., 2018. Biological control using invertebrates and microorganisms: plenty of new opportunities. BioControl 63, 39-59. 